\title{
Margaret Harris* \\ Familiar Patterns and New Initiatives: UK Civil Society and Government Initial Responses to the Covid-19 Crisis
}

https://doi.org/10.1515/npf-2020-0044

Received September 23, 2020; accepted November 28, 2020

\begin{abstract}
This paper describes and analyses the response of UK civil society in the early months of the Covid-19 crisis, roughly the period March to July 2020. While focussing primarily on civil society actors, the paper includes an exploration of how civil society and the national government interacted with each other. It considers the extent to which responses to the Covid-19 crisis reflect familiar patterns of behaviour by civil society in the UK, and in the relationship between the government and 'third sector'. The paper concludes by pointing to emergent issues for civil society as the UK looked towards recovery from the initial wave of crisis.
\end{abstract}

Keywords: civil society, UK civil society, Covid-19, government response to Covid-19

\section{Introduction}

How should governments respond to the approach of a global pandemic? How should they prepare their citizens and their health services? What equipment and food should be stockpiled? Should they impose restrictions on population movements? How should they balance threats to health against threats to the economy or children's education? What expectations should be placed on civil society to partner with governmental agencies?

These major questions continued to be debated within the UK during the late summer of 2020 (when this paper was written) with little consensus about the wisdom of what the national government actually did during the early days of the Covid-19 crisis or about what it should be doing to prepare for future waves of infection . Indeed the lack of consensus about how to respond to the crisis was reflected from the start, in differing advice and response policies in different parts

\footnotetext{
*Corresponding author: Margaret Harris, Ph.D., Emerita Professor, Aston University, Birmingham, UK, E-mail: m.e.harris@aston.ac.uk
} 
of the UK. ${ }^{1}$ Yet if lessons are to be learned about social and public policy responses to pandemics, analysts will need not only retrospective historical analysis but also records of how the crisis was experienced and how civil society ${ }^{2}$ responded at the time. It is the purpose of this paper to provide such a contemporary record and to explore emergent policy and organisational themes.

The paper draws on documentary material from contemporary news reports and commentaries, in print and electronic media, collected by the author in the period from the end of February to the end of July 2020; the initial phase of the Covid-19 crisis in the UK. In analysing the documentary materials collected, the author was informed not only by her knowledge of UK civil society behaviour in pre-Covid-19 times but also by her own experience of living through the evolving crisis in an English suburb, as both a citizen and a volunteer. Nonprofit and civil society scholars are often participants in the very phenomena which they study and this experience can add value to their research when used, as here, in a reflexive manner (Dean 2017; Glassner and Hertz 2003; Harris 2001).

The paper highlights four aspects of UK civil society activity in the initial weeks of the crisis: local responses to the needs of those identified as vulnerable; volunteering with established charities; spontaneous volunteering; and challenges of organisation and governance. It goes on to point to five aspects of civil society activity in the UK during the period April-July as civil society responses to the crisis consolidated: digital volunteering; network formation; citizen support for the NHS; the national government's own initiative to recruit volunteers; and formalisation of spontaneous informal initiatives.

The latter part of the paper moves beyond description to propose points of note for public policy. It considers the extent to which responses to the crisis reflect earlier patterns of civil society behaviour ${ }^{2}$ and earlier patterns in the relationship between government and the 'third sector' in the UK. It also looks at where the

1 The 'United Kingdom of Great Britain and Northern Ireland' (the UK) has a national Government based in Westminster, London which is currently headed by Boris Johnson as Prime Minister. Constituent nations of Northern Ireland, Scotland and Wales each have varied and limited powers to order some of their own affairs. Accordingly, Covid-19 mitigation policies have been implemented in differing ways in each of the areas. In this paper we refer to the behaviour and policies of the national UK government and to the behaviour and policies of local governmental authorities in England.

2 This paper follows an international tradition of using the term 'civil society' as a synonym for the variously termed 'nonprofit', 'third', 'voluntary' or 'NGO' sector; the sphere of organised activity which is neither governmental nor commercial in its auspices. In this sense, civil society includes not only formal service-delivering organisations but also smaller third sector organisations with few or no paid staff; political associations; voluntary membership associations; local community organisations; mutual aid groups; volunteering; groupings with philanthropic intent; public protest and dissent; e-activism; on-line petitioning; and spontaneous barely-organised actions (Eliasoph 2013; Habermas 1989; Harris 2017). 
Covid era patterns appear to be different, since it is often in differences that we can discern the emergence of new trends and new responses to social need (Timmerman and Tavory 2012). The paper concludes with some indications of emergent issues for civil society as the UK looked towards recovery from the initial period of crisis in the late summer of 2020.

\section{Civil Society Responding to the Covid-19 Crisis: Two early phases}

This paper is structured around themes emerging from an analysis of documentary data. The initial response by UK civil society to the crisis is conceptualised as occurring in two distinct but overlapping phases. The first phase can be seen to have occurred from the end of February 2020 to roughly mid-April when infection and death rates were peaking and when civil society was hyper-active. In this phase, responses to the crisis from civil society as well as politicians were focused on health and social care including basic physical survival within the population. The second phase can be seen to have occurred from roughly mid-April to July 2020 when there was a growing sense of the pandemic coming under control, reflected in the gradual easing of restrictions from early May. During this second phase politicians' focus shifted more towards education, employment and the economy, matters which had had less attention when the main focus was on saving lives and sustaining health and social care services. The next two sections examine these phases in turn.

\section{Civil Society Hyper-Active Initial Response Phase}

This section of the paper does not seek to provide a comprehensive account of all civil society responses in the early weeks of the UK crisis. It focuses on those civil society activities which emerged from a thematic analysis of documents available in the late summer of 2020 when the research for this paper was conducted. It highlights four key forms of civil society activity in the UK as the crisis deepened and as civil society itself became pro-active in responding to the crisis: local responses to the needs of the most vulnerable in the population; volunteering with established charities and voluntary associations; spontaneous initiatives; and challenges of organisation and governance. The four aspects were not in practise 
self-contained but are presented separately here for clarity and to highlight the range and variety of civil society activity in the period.

\subsection{Responding Locally to Vulnerable People}

The broad context for the civil society response to vulnerable people in the first few weeks of the crisis was a UK government policy published on 21 March (Public Health England 2020) intended to identify and advise people considered to be 'clinically extremely vulnerable' to complications should they be infected with the virus. Initially this identified group comprised an estimated 1.5 million people with certain underlying health conditions. They were identified from National Health Service (NHS) records and were requested to remain within their own homes for at least an initial three month period. This group, designated as 'shielded', were to be provided with free food supplies delivered weekly to their homes, as well as social support in the form of 'check in' phone calls. Local governmental authorities were charged by the national government with implementing this response but in practise they were only able to do so by recruiting and managing volunteers, either new temporary volunteers, or volunteers already associated with local community and voluntary agencies with which the local authorities had pre-existing collaborative relationships (LGA 2020).

The implementation of the 'shielding' policy was intended to ensure the basic physical survival of a small but extremely vulnerable minority of the population. However, it left a much larger, second-tier, group of people (at least a further 10 million) identified in government guidance as being at 'moderate risk' but for whom no governmental support plans were in place. This was a group identified in the national government's own communications as vulnerable ('likely to be more seriously affected') by reason of age (being over 70) or because of underlying medical conditions including common conditions such as diabetes and heart disease (NHS 2020; UK Government 2020a). The government issued advice about how this group should minimise contacts with others (by avoiding going out to buy groceries or collect prescription medication for example) but offered no physical or social forms of support, even for those living alone. Their difficult position was aggravated on 23 March when the whole country was placed 'in lockdown' (that is the country was told that all non-essential social contact must cease) and accessing essential supplies became increasingly difficult for the whole population.

The problem of obtaining essential supplies if you were in the second-tier vulnerable group advised to 'socially isolate', was exacerbated by the fact that major supermarkets were unable to gear up quickly to meet the increased demand for home delivery or even to replenish their in-store stocks (Butler, S. 2020). In any 
case, since home food delivery was only accessible to those with computers, internet connections and the capacity to use them, some of the most vulnerable were not only excluded from access to online government information but were also unable to obtain food deliveries . Thus, those in the second-tier at-risk group who did not wish to flout social isolation guidance and could not rely on nearby family and friends, were reliant during March and early April on grassroots initiatives within civil society for the very basics of life.

In the early days of March, individuals and small informal groups took their own initiatives to try to ensure that nobody at their own local level was left without social contact and a volunteer to help with essential tasks. Such initiatives included placing home-reproduced notes through house doors offering help. News of early informal initiatives were widely shared through social media and widely imitated, to the extent that most parts of the country were covered by informal community-level initiatives during March. Very quickly many individual neighbourhood-level initiatives shared knowledge and ideas and formed themselves into local, then national, networks under the banner of 'Covid-19 Mutual Aid', guided by a principle of 'community reciprocity' rather than 'delivery of services' to those in need (Tiratelli and Kaye 2020).

\subsection{Volunteering with Established Charities and Voluntary Associations}

Whereas 'Covid-19 Mutual Aid' activities were a specific response to the crisis, were initiated at the grassroots, and remained informal and self-regulating, much volunteering also occurred via established charities and other formal third sector organisations. Many of those wanting to help in the crisis who did not regard themselves as being in the most at-risk categories, initially approached national organisations, such as the British Red Cross or the Salvation Army, or social welfare organisations such as those run by religious groupings, Caritas and Jewish Care for example (ICN 2020). Many people dismissed or 'furloughed" 3 from their regular employment turned to volunteering as a replacement activity and such people swelled the numbers of those available to volunteer during the early weeks of the crisis (Tiratelli and Kaye 2020)

It later became known, that established volunteer-involving organisations were not in practise able to involve all the people who came forward to help in the early weeks of the crisis (Butler, P. 2020). Charities were not geared up to integrate

3 The widely used American term 'furlough' refers in the UK to the Government's 'Job Retention Scheme' first announced in April 2020 and due to be phased out by October 2020 (HMRC 2020). 
and manage a major influx of new untrained volunteers, they did not have many additional opportunities for volunteers, and, as formally regulated organisations, they were under an obligation to carry out costly and time-consuming safeguarding checks on potential volunteers before involving them.

\subsection{Spontaneous Volunteering}

The examples of compassion and willingness to help mentioned above can be seen as illustrations of the well-studied phenomenon of 'spontaneous volunteering' which commonly occurs in times of crisis such as floods, hurricanes and earthquakes (Harris et al. 2016; Michel 2007). Numerous examples of spontaneous acts of kindness to other human beings were reported in the early days of crisis including, for example neighbours offering cooked food to each other. Children locked down at home displayed in windows hand-painted rainbow symbols of support for NHS workers (Doyle 2020). An initiative during the total lock-down period to urge people to stand in front of their homes on Thursday evenings at 8.00 pm to 'clap for the NHS' rapidly spread throughout the country and became institutionalised as a moment of noisy citizen solidarity as well as a gesture of appreciation for the NHS (NHS Royal Free 2020).

Two aspects of the spontaneous volunteer response to the Covid-19 response are noteworthy because they reflect special features of the Covid crisis in the UK. One aspect was the numerous examples of individuals or small friendship groups attempting to fill gaps in NHS health care services which are normally regarded as a governmental responsibility. ${ }^{4}$ Thus individuals were reported to be making visors for NHS staff on home 3D printers or making medical scrubs on home sewing machines as reports came in about shortages of personal protective equipment (PPE) for front-line staff. Individuals were also reported to be collecting moisturisers and bottles of water for hospital staff or delivering home-made snacks for staff on break periods (ECHO 2020). These can be seen as micro-initiatives within civil society in the face of macro needs and gaps in governmental provision.

The second noteworthy aspect of the spontaneous volunteering was the way in which regulations, safeguards and formal management systems were bypassed with impunity in the face of an overwhelming national crisis and the keenness of

\footnotetext{
4 Although the UK's NHS (National Health Service) is essentially a governmental agency and a creature of the original 'Welfare State' of the 1940s, it is widely seen as an institution separate from government and attitudes to the NHS are not necessarily the same as attitudes to national government at any one time. The NHS has retained its place as a respected and loved institution (Lowe 1999); the respect was reaffirmed at the time of the 2012 London Olympics when it featured prominently in the opening ceremonies, and during the Covid-19 crisis as described in this paper.
} 
volunteers and donors to just 'do something' (Tiratelli and Kaye 2020) Thus there was no public mention in the early weeks of food standard regulations, security risks posed by unscreened volunteers and cash donations, safeguarding issues, data privacy and the need to train volunteers. From the start of the crisis hospitals and clinics put strict measures in place to try to limit the spread of infection within and between their facilities, measures which they were already well prepared to implement. But as gaps appeared in provision not only for patients but also for those treating patients, the emergency situation prompted a relaxation of rules normally enforced on civil society actors (Charity Commission 2020).

Over time spontaneous initiatives morphed into more formal networks or projects or were incorporated into more established third sector organisations - as will be shown in the next section of this paper which looks at the second phase of the civil society response.

\subsection{Challenges of Organisation and Governance}

The Covid-19 crisis in the UK led to a rapid rise in demand for services provided by established charities. ${ }^{5}$ There was particular demand for services for people whose usual support and care needs could no longer be met by themselves or by their own networks; including homeless people, or those in need of specialist medical care, income or food help, practical daily help or help with child care and education. At the same time as there was a huge increase in demand for third sector services, those same agencies experienced steeply increased costs associated with adapting their provision to the pandemic situation and recruiting more staff and volunteers (NCVO 2020; Weakley 2020).

This steep rise in demand for services combined with increased costs, presented third sector boards and senior staff with an insoluble dilemma since they occurred precisely at the moment when it became clear that future funding of their organisations was in jeopardy because of restrictions on in-person encounters, arising from the pandemic (Kenley 2020). Most UK third sector organisations do not have substantial reserves; in fact philanthropic donors and regulators may discourage the accumulation of reserves, arguing that money donated for public benefit should be spent on public needs (Calabrese 2013). Thus many UK charities and voluntary associations (including religious organisations such as local churches) operate on a year-by-year basis, reliant on thrift shops, events and fundraising campaigns to bring in a high proportion of their yearly income.

5 That is, those third sector organisations recognised by the Charity Commission for England and Wales or equivalent bodies in Scotland and subject to legal regulation. 
The social distancing imperatives of the Covid-19 crisis, then, presented civil society organisations with a threat of vastly reduced income at the very time when demand for services and associated costs were increasing rapidly and unexpectedly. In effect, the legal and ethical obligations placed on charity trustees at the start of the pandemic pulled them in opposing directions: to meet the needs of those they were set up to benefit and also to act prudently to ensure the long-term survival of their organisations.

The national government's furlough scheme ${ }^{3}$ which was primarily intended to help for-profit businesses survive the crisis, provided an incentive to incomestrapped third sector organisations to release their own staff from work duties in order to try to ensure their organisations' longer term survival. Yet insofar as third sector organisations availed themselves of the furlough scheme, they were then less able to deliver the very services which were their raison d'etre and at a time when demand for those services was at its peak.

\section{Civil Society Consolidation Phase}

The second phase of the initial civil society response to the Covid-19 crisis began around the middle to end of April when there was a growing sense that the infection was coming under control and that the severe lockdown restrictions might be eased. Politicians and commentators started to look towards consolidation of early responses and, indeed, to the start of 'recovery'. At this time politicians' focus shifted more towards education, employment and the economy, matters which had necessarily had less attention when the main focus was on saving lives and ensuring the continuation of health and social care services. At the beginning of April, and following intensive lobbying, it was announced that the Government would offer $€ 750$ million in new funding for charities responding to the crisis, of which nearly half would be for smaller community charities; amounts immediately condemned as far too little by charities themselves (House of Commons 2020; NCVO 2020; UK Government 2020b).

By the middle of April local and regional governmental authorities had (mostly successfully) found ways to implement the distribution of help to the 'shielded' group, albeit with the cooperation of local community groups and volunteers. Local civil society networks were sufficiently well organised to be confident that neighbours in need had been identified and were being helped to obtain groceries, prescription drugs and social support. The whole country was still 'in lockdown' but emotions stirred up by the high rates of death and illness, and the outstanding commitment of hospital workers generated feelings of solidarity in the population. 
This section of the paper highlights five aspects of civil society activity in the UK during the spring and summer period of 2020, up to roughly the end of July: digital volunteering; network formation; citizen support for the NHS; the government's own initiative to recruit volunteers to support the NHS; and formalisation of spontaneous informal initiatives. As with the section above on the first hyperactive phase of civil society response, we do not attempt here to provide a comprehensive account of all civil society activity in the UK in the second phase of response. Rather we point to themes which emerged strongly from analysis of the available documentary data.

\subsection{Digitally Facilitated Citizen Action}

In the first days and weeks of the Covid-19 crisis the ability to use digital technology to obtain information and keep in contact with those beyond your own household was at a premium. Those without access to a computer and the internet at home (which included children not at school and people obliged to work from home) were at a major disadvantage. There was a rapid rise in learning of new technologies but this also meant that, as time passed, there was a widening of the gap between those who were 'digitally enabled' and those digitally excluded (the latter including many of the most vulnerable in the population and those with the lowest incomes) (Watts 2020). The implications for civil society were simultaneous increases and decreases in social connectedness, social solidarity and access to information.

There was also an increase in digitally-enabled volunteering as those in lockdown at home or designated as 'vulnerable' could nevertheless support friends and neighbours or become involved with distanced volunteering schemes (see, for example, AgeUK 2020).

\subsection{Network Formation}

Many of the informal grassroots groups initiated at the start of the crisis and intended to support vulnerable people, gradually formed themselves into mutually-supporting networks under the banner of 'Covid-19 Mutual Aid'. By midApril these local networks were themselves forming into a nation-wide network, sharing ideas and guidelines for volunteer recruitment and management (Tiratelli and Kaye 2020).

Other networks also developed during the consolidation phase, especially at the local level where informal links were made between civil society activities. 
For example, groups providing cooked meals for homeless people made links with food banks so that surplus ingredients and meals were donated on rather than wasted. Similarly food banks formed links with local distributers of government food boxes to 'shielders', so that unwanted content of the free food boxes could be passed on to others in need. Local religious congregations made links across faiths to tackle local support and care needs (IFN 2020).

Networking also occurred between the more formal volunteer-involving charities and associations. Many such formal organisations could not involve all the volunteers who approached them at the start of the pandemic but as it became known that this was a widespread phenomenon, systems were initiated for organisations to refer surplus potential volunteers to other charities who needed them. Specialist schemes were also initiated to provide volunteering opportunities for people on furlough (e.g. JVN 2020).

\subsection{Grassroots Support for NHS Staff}

As mentioned earlier in relation to 'spontaneous volunteering', there was an outpouring of support - practical and moral - for NHS hospital staff as stories emerged in March and April about the extreme stress being experienced by hospital workers on Covid wards. Staff were working extended shifts wearing uncomfortable protective clothing and attending to very sick and dying patients (Royal Free London 2020). Some hospitals were reported to have severe shortages of PPE for front-line staff (Kale 2020). They needed more than gestures of solidarity such as the Thursday night clapping and children's pictures of rainbows. They needed practical gestures such as help with obtaining groceries for their own households, skin hydrating products, easy-to-eat meals for their short breaks and ipads/tablets to enable patients to communicate with loved ones who were banned from visiting. Numerous initiatives developed at the local level to support hospitals including collecting donated items and offers of car parking spaces from nearby residents. These spontaneous gestures of help for NHS staff were consolidated and formalised after the early weeks.

Although the NHS is essentially a governmental agency ${ }^{4}$, it has hybrid features including charitable fundraising arms attached to hospitals. These 'hospital charities' had existed for many years but they came into the spotlight as the Covid-19 crisis continued and they became recipients of donations for "nonessential' items to support NHS staff, including mental health services. By July 2020, the network of such hospital charities called 'NHS Charities Together' had received $€ 130$ million in public donations (UKFundraising 2020). 


\subsection{NHS Emergency Responders Scheme}

At the end of March when the infection rate was soaring and the country was in lockdown, the national government, in partnership with some large national charities including the Royal Voluntary Service launched an appeal for the public to participate in a volunteering programme to 'support the NHS'. This launch was apparently prepared without reference to voluntary sector infrastructure bodies or any charities except the handful already trusted as partners by national government. It was totally separate from the various civil society initiatives mentioned so far in this paper. The government initiative was marketed as one intended to provide support for non-hospitalised NHS patients (not necessarily Covid-19 patients) who needed help with shopping, medicine collection and telephone contact (GoodSAM 2020).

As shown in the previous section of the paper, local grassroots initiatives had been performing these very tasks at the local level from the start of the crisis. The government initiative came at a point when vulnerable people (other than the identified 'shielded' group) had been left to fend for themselves for many weeks. The NHS project had some additional features in that, controversially and in defiance of isolation guidelines at the time, it appealed for volunteers to drive people to and from medical appointments. It was also dependent organisationally on a phone app ('GoodSAM') which matched volunteers on standby shifts to people referred to the scheme by NHS doctors as needing help.

It was reported that 750,000 volunteers had been recruited to the scheme by 29 March (GoodSAM 2020) but later anecdotal evidence suggests that only a small proportion of the people recruited as volunteers were actually deployed and of those, only a small proportion had more than a handful of referrals to them. In short there was over-recruitment. Many people came forward out of loyalty to the NHS which is a much loved national 'institution" ${ }^{4}$ but the scheme was apparently launched without awareness of how much voluntary 'helping' had already been taking place at a local level and without an assessment of the numbers of volunteers needed for the NHS scheme.

\subsection{Formalisation of Spontaneous Initiatives}

In the previous section we described the numerous helping initiatives which sprang up during March in the early days of the crisis. During April and May many of those informal initiatives coalesced with others and gathered momentum. As they grew they became more systematically organised, while remaining essentially informal initiatives below the radar of regulatory authorities and enforcement agencies. An example of one such initiative is provided in this section to illustrate 
the process of rapid growth and formalisation which occurred after the initial phases of enthusiasm and unregulated hyper-activity. It draws on the author's interview with 'Amy', founder and leader of a local spontaneous initiative called 'You donate, we deliver'. 6

When the Covid 19 crisis was developing during March, Amy heard that a friend was baking treats for family members who were NHS hospital staff. Amy and her daughter, who is a chef but was on furlough, made 130 muffins one day to be distributed to hospitals. Amy then heard that hospitals were asking for help for staff on Covid wards who did not have time to cook for themselves or eat properly during shifts or even get food from the hospital canteen. They needed more than treats; they needed full nourishing meals. Amy and her daughter started making and packing meals which could be quickly heated in a microwave oven. But when it got to 100 meals a day it was too much for the two of them. So Amy asked friends for help and also put out an appeal for local helpers on social media. She had an overwhelming response: 'Everybody was frightened and everybody wanted to help'.

Demand from hospitals for meals for staff on Covid wards increased and Amy realised in April that 'we would have to set up a fund for food ingredients and involve the wider community'. 'You Donate, We Deliver' was established online with crowdfunding. Its centre of operations, for administration and for cooks' collection of donated food items, was a small tent set up in the front yard of Amy's home. By mid-May Amy was coordinating a local team of volunteers sourcing food, and making and delivering about 600 meals a day. She herself developed at-speed the food hygiene rules for cooks to follow. Her local group was linked into a network of similar groups: 'an army of amateur and professional chefs, 10 community hubs, and 17 delivery drivers', all of them volunteers. Early in June, as Covid restrictions were easing, community infection rates were falling and some volunteers were returning from furlough to employment, the initiative was wound up.

\section{Discussion}

\subsection{Familiar Patterns of Civil Society Activity?}

Did the Covid-19 crisis give rise to new kinds of civil society behaviour? Certainly it seems to have accelerated the pre-existing trend towards micro and digital

6 The transcript of the interview was shared with Amy (not her real name) for checking and she willingly agreed to it being shared in edited form in the context of an academic paper. The interview was conducted by telephone due to Covid-19 restrictions on face to face meetings at the time, June 2020. 
forms of volunteering which people can do from their own homes if they have access to computer technology (Jochum and Paylor 2013). Similarly there are indications that it may have encouraged those who had not volunteered before to see volunteering as an opportunity to help others and help themselves; so it is possible that the total levels of volunteer involvement will be found to have increased as a result of the crisis, especially if there is a steep rise in unemployment and people seek alternative ways of using their time while preparing for return to paid employment (Roffe 2020). Yet, most of what has been described in this paper seems mostly to confirm patterns already noted in earlier literature about the pre-Covid era.

For example, past researchers have noted how an outpouring of spontaneous volunteering occurs in times of emergencies such as flood or earthquakes (Michel 2007; Twigg and Mosel 2017). Citizens 'arrive' when emergencies arise, often bringing their own equipment and their own ideas about how to respond. Many such volunteers will not wait to be guided or directed and will not necessarily approach established charities or official emergency responders. Earlier literature on disasters has pointed to the wish of established charities for spontaneous volunteers to work through them (Harris et al. 2016). The current paper adds a proviso to this in that there was some evidence that those who wanted to volunteer in the early weeks of the Covid-19 crisis could not in fact be absorbed by established charities which were not geared up to rapidly check, train and integrate large numbers of new volunteers.

Literature on disasters and emergencies has also noted the crucial role of social media in informing people about where help is needed, what help is needed and how people might respond appropriately (Alexander 2014). Social media can rapidly put those in need in touch with those offering help and disseminate information about changing locations of need. After the initial confusion which often accompanies the start of a crisis, social media also provide signposting to established agencies which can involve volunteers or direct them to opportunities. Similarly, during the early stages of the Covid-19 crisis in the UK, social media were an important means through which information was communicated at the local level about those who needed help and what kinds of help were needed. Social media were also important in generating support for NHS staff and in promulgating innovative ideas for expressions of citizen solidarity.

Where social media were less helpful in the Covid-19 case was in giving advice and information to some of the most vulnerable and those most in need of help. 
If they did not have home access to the internet, they could not access the various guidance documents issued online by government agencies. ${ }^{7}$ Thus the Covid-19 crisis revealed both the benefits of social media in facilitating civil society activity and also its limitations.

Other patterns described in this paper also echo earlier literature, including the way in which civil society, even where it appears to be inactive or dormant will be roused into swift responsive action in times of crisis (Milofsky 2008; Solnit 2010). This point applies especially to neighbours who can become the main source of help with basic needs in times of disaster (Rosenblum 2016). In the case of the UK Covid-19 crisis, it took several weeks for national and local governmental agencies to set up systems for distributing help to the identified 'shielding' group. During this time, civil society groups at the community level not only identified and responded to local needs, they also cooperated extensively with local governmental authorities in meeting urgent needs (Locality 2020).

The stereotype of civil society as flexible, responsive and innovative (Kramer 1981; Milbourne 2013; Wolch 1989) is largely confirmed by the current study. At the neighbourhood level people rapidly self-organised (Twigg and Mosel 2017); improvising systems for identifying and contacting those in need of support and ignoring, where necessary, regulations on data protection and safeguarding in order to deal with threats to human survival (Rosenblum 2016). They developed new schemes for involving volunteers in new ways, such as special volunteering schemes for those furloughed. They collaborated, coordinated and supported local governmental care responses without waiting for formal protocols or payment systems to be developed. And as time passed, they developed informal networks to provide mutual support between initiatives to ensure that resources were used efficiently and not wasted because of competitive behaviour. The drive to collaborate overrode the drive to compete. At the more formal level of established charities, trustees stepped up quickly to support paid staff and get involved with operational activities; a phenomenon also noted in earlier literature about nonprofits in organisational crises (Wood 1996).

7 In fact, this point seems to have been recognised at an early stage by the national government as the 'shielded' group were informed about their status, and about the arrangements to support them by hard copy letters sent in the mail. Similarly the first comprehensive advice from the national government about the crisis (UK Government 2020a) was delivered directly to people's homes in hard copy leaflet format. 


\subsection{Common Patterns in Government/Civil Society Relationships?}

The data suggest that many features of the relationship between government and civil society in the early months of the crisis, also echo earlier findings about that relationship.

As suggested by theories which conceptualise the third sector in welfare states playing a supplementary and/or complementary role in relation to state services (Young 2000), the UK government in the crisis period took a lead role in identifying, and responding to the needs of, those who were extremely vulnerable (the 'shielders'). Their very lives were under threat. One of the government's first Covid19-related decisive actions was to set up systems to meet basic survival needs of this group. What is noteworthy about the Covid-19 example, however, is how low the government set the ceiling for taking responsibility for the care of vulnerable people. It identified just 1.5 million people as 'extremely vulnerable' and tried to ensure their basic survival needs were met. Yet the next most vulnerable group of over 10 million, although identified from the start by government, received no governmental support, even though they were told to 'socially isolate'. It was left to civil society in the form of established charities and local grassroots initiatives to respond to the needs of this category of people.

Subsequent recognition by national government of this vital gap-filling role performed by civil society in the first weeks of the crisis has been sparse, limited to schemes whereby established charities can apply by competition for small grants to help fund retrospectively some of their Covid-related services (NPC 2020). As in past examples of cooperation and complementarity between civil society and governmental services (Aiken and Harris 2017; Harris 2012) there has been a tendency to blur the boundaries in public discussion about contributions of the two sectors. There has been a generic focus on response and care. The impression conveyed in policy statements has been that it is governmental agencies which have been most effective in responding to crisis. This can be seen as a form of government encroachment into civil society territory (Harris 2017).

This blurring of sector boundaries was evident too in the setting up of the NHS Responders' Scheme where the government's chosen partners were large longestablished national charities. Despite the heavy input from those charities into recruitment and management of the NHS volunteers, the initiative has been badged as an NHS (i.e. governmental) initiative. As has been noted before (Cairns and Harris 2011), governmental agencies which collaborate with the third sector, tend to feel most comfortable working with formally structured charities whose organisational form is familiar. Also, as in this case, when drawing in volunteers to support governmental provision, they tend to 'go large' which can lead to 
bureaucratic rule-bound provision which negates the very rationale for drawing in volunteers in the first place (Harris 2012)

Although there are some similarities between features of the government/civil society relationship before and during the Covid crisis, some aspects of the relationship during the crisis are distinctive. One feature arises from the fact that national government quickly delegated care of the extremely vulnerable to local and regional levels of government. This opened up possibilities for local civil society groups to become involved in crisis care responses, nominally led by local governmental agencies. A second noteworthy feature is the way in which guidelines and regulations for the third sector, which have become increasingly tight and sanction-enforced in recent years in the UK, were relaxed at the height of the crisis; some officially relaxed (Charity Commission 2020) and some by 'turning a blind eye' to matters such as data privacy, safeguarding and food safety Third, in this crisis, and in response to strong lobbying, the national government instituted some limited schemes to provide financial support to charities and associations when it became clear that their usual fundraising sources would not be forthcoming due to the Covid-19 crisis and related economic and social impacts.

\subsection{Emergent Issues}

This paper has provided a snapshot of civil society activity in the early months of the Covid-19 crisis in the UK, using contemporary data. The future for civil society in the UK is inevitably uncertain and dependent in part on the future trajectory of viral infection. All the same, we can conclude this look at the first few months of the Covid-19 crisis by noting some emerging issues as at September $2020 .^{8}$

As in other countries, UK civil society organisations which are dependent on yearon-year fundraising (for example, through small cash collections, charity dinners and thrift shops) are struggling to survive financially, as indicated above (Dayson 2020). At time of writing it seems that we can expect further large-scale staff redundancies and services cuts, along with a greater willingness to collaborate between the groupings and organisations within civil society. In fact, there are indications that the civil society landscape is likely to emerge from the crisis looking very different in terms of composition, funding sources, staff structure and volunteer engagement.

8 Future researchers of civil society in the early months of the Covid period in the UK will have access to more documentation and information than was available to the author at the time of writing this paper in the late summer of 2020. This paper is inevitably limited by the data available at the time of writing and the need to pause the research process to meet the agreed schedule for the production of this Special Issue. It stands with other papers in this volume as a contemporary snapshot of civil society activity in an exceptional historical period. 
These trends, in their turn, can be expected to place major stress on volunteer governing boards and, as organisational belts are tightened, there is likely to be withdrawal of services provided by civil society organisations in pre-Covid times. In the UK, this is especially concerning because it is some of those most in need due to the Covid-19 crisis who are most dependent on third sector services, for example people who are homeless, in poverty or experiencing mental ill-health. At the time of writing in late Summer 2020, there are credible indications that children and young people will have remedial needs due to long absences from education, and that the UK criminal justice system is snarled in extensive delays which third sector law centres could help to alleviate if they are able to continue in operation. The crisis has revealed the extent to which major social problems in the UK (including people trafficking, substance abuse and domestic abuse) are now responded to largely by third sector organisations and groups whose very survival may be under threat due to the impact of the pandemic on civil society. It remains to be seen if financial support to civil society organisations becomes one of the national government's spending priorities. Meanwhile we can expect patchy provision of care and other services provided by civil society actors, and lack of long-term investment in medical and other forms of research by third sector organisations as they switch available resources to funding current service provision and to responding to the impact of the pandemic.

As the crisis abates it is to be expected that there will be less tolerance of regulation avoidance and a return to tight control of civil society (Charity Commission 2020). In the light of the apparent success of the NHS volunteering scheme, we may expect a return to an overtly instrumental view by government of civil society as a useful 'service provider'. We can also anticipate that, drawing on the experience of the crisis, there will be further projects to draw volunteers into implementing the government's own policy agenda along with a lack of interest in boundaries between the governmental and civil society sectors (Einasdottir and Osia 2020; Kruger 2020). This latter point is perhaps concerning for those who value a strong and independent civil society as a counterpoint to powerful governments (Harris 2017; Harris and Milofsky 2019).

On the more positive side, it seems reasonable to anticipate a resurgence of civil society activity associated with the Black Lives Matter movement as the crisis abates and renewed cooperation between ethnic and faith groups building on the trust generated during the crisis. We may also see a proliferation of innovative forms of fundraising within civil society as charities adapt to the loss of income from events and thrift stores.

There is an expectation amongst volunteering infrastructure charities that there will be an upsurge in volunteering from those who have enjoyed their volunteering experiences in the Covid era and have experienced the satisfaction that 
comes from helping others and working in solidarity with neighbours. Such new and renewed commitment to citizen voluntary activity will be needed more than ever as the Covid-19 tide retreats.

\section{References}

Age UK. 2020. Become an AgeUK Digital Buddy. https://www.ageuk.org.uk/get-involved/ volunteer/become-an-age-uk-digital-buddy/ (accessed September 1, 2020).

Aiken, M., and M. Harris. 2017. "The Hollowing Out of Smaller Third Sector Organisations?" Voluntary Sector Review 3 (10): 333-42.

Alexander, D. 2014. "Social Media in Disaster Risk Reduction and Crisis Management." Science and Engineering Ethics 20: 717-33.

Butler, P. 2020. A Million Volunteer to Help NHS and Others during Covid-19 Outbreak Guardian. https://www.theguardian.com/society/2020/apr/13/a-million-volunteer-to-help-nhs-andothers-during-covid-19-lockdown (accessed August 31, 2020).

Butler, S. 2020. UK Supermarkets Struggle to Cope with Surge in Online Orders. Guardian. https:// www.theguardian.com/business/2020/mar/13 (accessed August 18, 2020).

Cairns, B., and M. Harris. 2011. "Local Cross-Sector Partnerships; Tackling the Challenges Collaboratively." Nonprofit Management and Leadership 21 (3): 311-24.

Calabrese, T. 2013. "Running on Empty: The Operating Reserves of US Nonprofit Organizations." Nonprofit Management and Leadership 23 (3): 281-302.

Charity Commission. 2020. Coronavirus (COVID-19) Guidance for the Charity Sector. London: Charity Commission. 7 April.

Dayson, C. 2020. Real-Time Evaluation of Leeds Neighbourhood Networks: Response to the Covid-19 Pandemic Leeds. Leeds, England: Centre for Ageing Better.

Dean, J. 2017. Doing Reflexivity. Bristol: Policy Press.

Doyle, L. 2020. Rainbows in Windows. Express. https://www.express.co.uk/life-style/life/ 1264214/Rainbows-in-windows-why-coronavirus-rainbow-drawings-chase-the-rainbow (accessed August 25, 2020).

ECHO Hospital and Community Healthcare Charity. 2020. Thank You for Supporting Your NHS during Covid-19. https://www.eastcheshire.nhs.uk/latest-news/Thank-you-for-supportingyour-NHS-during-COVID-19.htm (accessed August 31, 2020).

Eliasoph, N. 2013. The Politics of Volunteering. London: Polity.

Einarsdóttir, A., and S. Osia. 2020. “That's My Job': Tensions between Employees and Volunteers in the Fire Service." Nonprofit and Voluntary Sector Quarterly 49 (14): 871-89.

Glassner, B., and R. Hertz. 2003. Our Studies, Ourselves. Oxford: Oxford University Press.

GoodSAM. 2020. NHS Volunteer Responders. London: NHS, 29 March. Also Available at: https://www.goodsamapp.org/NHS.

Habermas, J. 1989. The Structural Transformation of the Public Sphere. Cambridge,Mass: MIT Press.

Harris, M. 2001. "The Place of Self and Reflexivity in Third Sector Scholarship: An Exploration." Nonprofit and Voluntary Sector Quarterly 30 (4): 747-60.

Harris, M. 2012. “London's Olympic Ambassadors: A Legacy for Public Policy Implementation?” Voluntary Sector Review 3 (3): 417-24. 
Harris, M. 2017. "UK Civil Society: Changes and Challenges in the Age of New Public Governance and the Marketized Welfare State." Nonprofit Policy Forum 8 (4). https://doi.org/10.1515/ npf-2017-0017.

Harris, M., and C. Milofsky. 2019. "Mediating Structures: Their Organization in Civil Society." Nonprofit Policy Forum 10 (2). https://doi.org/10.1515/npf-2019-0017.

Harris, M., D. Shaw, D. J. Scully, C. Smith, and G. Hieke. 2016. "The Involvement/Exclusion Paradox of Spontaneous Volunteering: New Lessons and Theory from Winter Flood Episodes in England." Nonprofit and Voluntary Sector Quarterly 46 (2): 1-20.

HMRC (Her Majesty's Revenue and Customs). 2020. Guidance: Claim for Wages through the Coronavirus Job Retention Scheme. London: HMRC.

House of Commons. 2020. "Appendix: Government Response" in the Covid-19 Crisis and Charities: Government Response to the Committee's First Report of Session 2019-21. London: House of Commons.

ICN. 2020. Westminster: Caritas Response to the Coronavirus. Independent Catholic News 13 March. https://www.indcatholicnews.com/news/39120 (accessed August 31, 2020).

IFN (Interfaith Network). 2020. Faith Communities Are Responding to Covid-19 in a Variety of Ways. https://www.interfaith.org.uk/news/covid-19-acts-of-kindness-and-service (accessed September 1, 2020).

Jochum, V., and J. Paylor. 2013. New Ways of Giving Time: Opportunities and Challenges in Microvolunteering. A Literature Review. London: NCVO.

JVN (Jewish Volunteering Network). 2020. Furloughed Staff Volunteering Opportunities. https://www.jvn.org.uk/furloughed (accessed September 1, 2020).

Kale, S. 2020. "Lost to the Virus." Guardian G2: 4-7. 13 August 2020.

Kenley, A. 2020. "Five Things we've Learnt about Civil Society during Covid-19." Civil Society Voices. 16 June 2020. https://www.civilsociety.co.uk/voices/anoushka-kenley-five-thingswe-ve-learnt-about-civil-society-during-covid-19.html (accessed September 1, 2020).

Kramer, R. 1981. Voluntary Agencies in the Welfare State. London: University of California Press.

Kruger, D. 2020. “Foreword." In (2020) Communities vs Coronavirus: The Rise of Mutual Aid, edited by L. Tiratelli, and S. Kaye, 5-6. London: New Local Government Network.

LGA (Local Government Association). 2020. Accessing Support: The Role of the Voluntary and Community Sector during Covid-19. London: LGA. 2 June.

Locality. 2020. We were Built for This. London: Locality.

Lowe, R. 1999. The Welfare State in Britain since 1945, 2nd ed. Basingstoke: Macmillan.

Michel, L. 2007. "Personal Responsibility and Volunteering after a Natural Disaster: The Case of Hurricane Katrina." Sociological Spectrum 27 (6): 633-52.

Milbourne, L. 2013. The Voluntary Sector in Transition. Bristol: Policy Press.

Milofsky, C. 2008. "Organizational Phoenix: Fighting the Incinerator.” In Smallville:

Institutionalizing Community in Twenty-First Century America Medford, edited by C. Milofsky, 50-67. Mass: Tufts University Press.

NCVO (National Council for Voluntary Organisations). 2020. The Impact of Covid-19 on the Voluntary Sector May 2020. https://publications.ncvo.org.uk/impact-covid-19-voluntarysector/key-points/ (accessed August 31, 2020).

NHS. 2020. Who's at Higher Risk from Coronavirus? https://www.nhs.uk/conditions/coronaviruscovid-19/people-at-higher-risk/whos-at-higher-risk-from-coronavirus/ (accessed August 31, 2020).

NHS Royal Free. 2020. 72 Years of our NHS. https://www.royalfree.nhs.uk/news-media/news/ 72-years-of-our-nhs/ (accessed August 25, 2020). 
NPC (New Philanthropy Capital). 2020. Where is the Government's $\mathrm{f} 750$ Million for Charities Being Spent? https://www.thinknpc.org/resource-hub/the-750m/ (accessed September 1, 2020).

Public Health England. 2020. Covid-19: Guidance on Shielding and Protecting People Defined on Medical Grounds as Extremely Vulnerable. London: Public Health England. 21 March.

Roffe, E. 2020. Citizens Advice Sees 30\% Rise in Volunteers Following Coronavirus Redundancies. Bedford Independent 20 August. https://www.bedfordindependent.co.uk/citizens-advicesees-30-rise-in-volunteers-following-coronavirus-redundancies/ (accessed August 23, 2020).

Rosenblum, N. 2016. Good Neighbours: The Democracy of Everyday Life in America. Princeton, N): Princeton University Press.

Royal Free London. 2020. BBC Hospital Special: Fighting Covid-19. www.royalfree.nhs.uk/newsmedia/bbc-hospital (accessed August 18, 2020).

Solnit, R. 2010. A Paradise Built in Hell: The Extraordinary Communities that Arise in Disaster. London: Penguin Books.

Timmerman, S., and I. Tavory. 2012. "Theory Construction in Qualitative Research: From Grounded Theory to Abductive Analysis." Sociological Theory 30 (3): 167-86.

Tiratelli, L., and S. Kaye. 2020. Communities vs Coronavirus: The Rise of Mutual Aid. London: New Local Government Network.

Twigg, J., and I. Mosel. 2017. "Emergent Groups and Spontaneous Volunteers in Urban Disaster Response." Environment and Urbanization 29 (2): 443-58.

UK Government. 2020a. "Coronavirus: Stay at Home, Protect the NHS, Save Lives." Leaflet delivered to Every UK Household, March 2020. London: HM Government.

UK Government. 2020b. The Chancellor Announces $f 750$ Million to Support the Charity Sector in Response to Coronavirus. 8 April 2020. https://www.gov.uk/government/speeches/ chancellor-of-the-exchequer-rishi-sunak-on-economic-support-for-the-charity-sector (accessed August 31, 2020).

UK Fundraising. 2020. NHS Charities Together Covid-19 Appeal. https://fundraising.co.uk/2020/ 07/03/nhs-charities-together-covid-19-appeal-reaches-130-million/ (accessed September 1, 2020).

Watts, G. 2020. “Covid-19 and the Digital Divide in the UK." The Lancet 2:e395-6.

Weakley, K. 2020. RNLI in an Impossible Situation over Reintroducing Lifeguards to Beaches. Civil Society News. 27 May 2020. https://www.civilsociety.co.uk/news/rnli-in-an-impossiblesituation-over-reintroducing-lifeguards-to-beaches.html (accessed September 1, 2020).

Wolch, J. 1989. "The Shadow State: Transformations in the Voluntary Sector." In The Power of Geography Winchester, edited by J. Wolch, and M. Dear, 197-220. Mass: Unwin Hyman.

Wood, M. 1996. Nonprofit Boards and Leadership. San Francisco: Jossey-Bass.

Young, D. 2000. "Alternative Models of Government-Nonprofit Relations: Theoretical and International Perspectives." Nonprofit and Voluntary Sector Quarterly 29 (1): 149-72. 